\title{
NEW VISION FOR BAHARIYA OASIS AS A CULTURE HERITAGE SITE
} Sayed Abuelfadl Othman AHMED *

Heritage and Museum Studies Department, Helwan University, Egypt

\begin{abstract}
This research focuses on one of our cultural and natural heritage site that is not well known in our society today, Bahariya Oasis. The purpose of this research is to discover the treasures of this site and introduce new vision to market it. In addition, the research focuses on the history of Bahariya Oasis through the Egyptian history, its treasures and how we can benefit from this site culturally an economically. This kind of heritage site suffer from ignoring and forgotten for a long time, therefore it is the time to try to discover and find good ways to market and put the site on the global map of tourism.

Keywords

Oasis, Heritage, Culture, Site, History, Desert, Tourism.
\end{abstract}

\section{Introduction}

The World Heritage Sites are designated by UNESCO's World Heritage Committee to be included in the UNESCO World Heritage Sites Program. These features may be natural, such as forests and mountain ranges, and may be man-made, such as buildings and cities, and may be mixed.

Each heritage site is the property of the state within its borders, but it receives the attention of the international community to ensure that it is preserved for future generations. All 189member States of the Convention are involved in the protection and preservation of these sites. The Egyptian Culture and Natural Heritage Sites are part of the UNESCO's World Heritage Sites list. This paper will focus on one of the Egyptian Heritage Sites that is in the tentative list, is Bahariya Oasis. This research will focus on the history of the Oasis, its cultural and natural heritage. And finally, the research will introduce a New Vision for Bahariya Oasis.

\section{Bahariya Oasis}

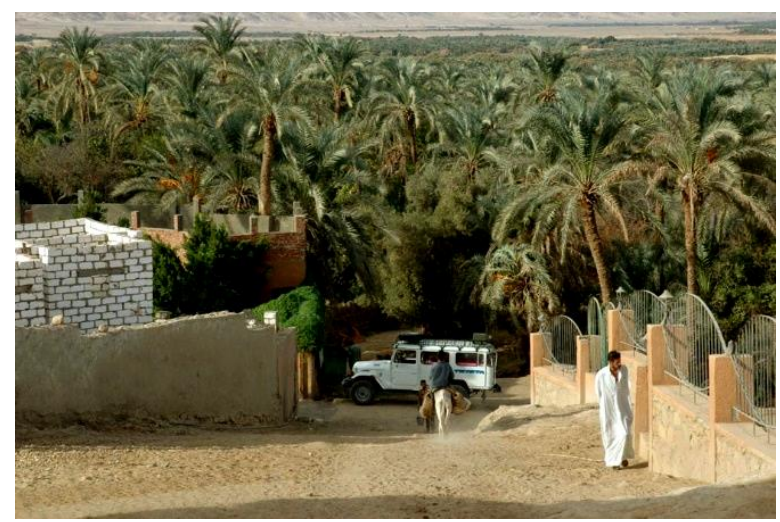

Fig. 1 Bahariya Oasis

*Corresponding author: sayed76@yahoo.com 
Bahariya Oasis is a depression, located in the western desert, $360 \mathrm{~km}$ from Cairo. It consists of Oases (Qasr - Mandishah - El-Bawiti - El-Hayz) and currently follow the governorate of Giza administratively and its current capital is El-Bawiti. the main economic sectors are agriculture, mining dates, olive and currently safari tourism. The agriculture products are dates, olives, guavas, and mangos (Egyptian Monuments, 2018).

El-Bawiti is considered the largest village and administrative center. Qasr is El-Bawiti's neighborhood. Mandishah has located to the east about ten kilometers away. El-Hayz is the southern village, it is far from the rest of the other villages, about fifty kilometers to the south of El-Bawiti (Kujanova, M., Pereira, L., Fernandes, V., Pereira, J. B., \& Černý, V., 2009).

The history of Bahariya Oasis dates back to the prehistory era. Archaeological excavations conducted in El-Hayz area, "north of Bahariya Oasis, about 37 km from El-Bawiti" revealed that the area was inhabited by the population in the middle of the Holocene geological era, a million years ago, and its people lived near the lakes that formed by rain, the area of this population was 20-200 square meters, but the actual area of these sites ranged from 20-80 square meters (Egyptian Monuments, 2018).

The archaeological remains recovered from these sites included the remains of stone tools, single and double-headed arrowheads, wide and sharp two-faced stone tools, two-pointed billet blades, remains of pieces of ostrich eggs (some of which were used as a perforator), and stone balls. There is influence relation between the stone tools in the oasis and the Late Paleolithic tools in the Deshna region of the Nile valley (Hassan, F. A., 1999). It is noted here that the word "oasis" refers to an oasis in general and not specifically to Bahariya Oasis. it may have been part of all the oasis of the Western Desert of Egypt at that time (Giddy, L. L, 1987).

The references to the existence of Bahariya Oasis dates back the $6^{\text {th }}$ dynasty, the Old Kingdom in the Ancient Egyptian History. The evidence was limited to the existence of relations between the Nile Valley and Western Oasis on the written documents, due to the lack of archaeological material available from Oasis of that era. The autobiography of Harkhuf, written on the walls of his tomb in Aswan, is documented in 58 columns inscribed on the front of the cemetery. He served in the reigns of King Merenre and Pepi II and became governor of Upper Egypt. He said on the right side of his grave: "Then His Majesty sent me for the third time to Iam." He went from the region in the way of the oasis .... " (Lichtheim, M., (2006).

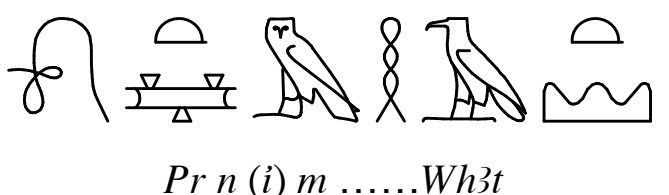


Through the first intermediate period, there were no references talking about Bahariya Oasis at that time. The Middle Kingdom witnessed a remarkable increase in activities and relations between the people of the Nile Valley and the people of the Western Desert of Egypt. The $12^{\text {th }}$ Dynasty began protecting the borders of Western Egypt by building a series of fortresses (Giddy, L. L, 1987).

The most important reference about Bahariya Oasis dates back to the end of the second intermediate period on a stela for the King Kamose when he referred to Bahariya Oasis in one of the texts of the Hyksos era, which may have stopped trade between the Nile valley and Oasis for lack of security (Hawass, Z. A., 2000).

It is likely that King Kamose had camped with his army in Bahariya during his military campaign against the Hyksos in the northern provinces (Bunson, M.R., 2002). The importance of Bahariya Oasis in the New Kingdom continued as one of the strategic and military points on the borders of Western Egypt. King Ramses II referred to Bahariya Oasis at the Temple of Amun in Luxor as a sacred place (Hawass, Z. A., 2000).

It suffered in the period between the end of the Persian rule of Egypt and the arrival of Alexander the Great to Egypt, like the rest of the Egyptian lands (Fakhry, A., 1950). But under the rule of the Ptolemies, Bahariya Oasis grew strong and active its economy and developed trade roads, especially those leading to Libya and established many military points. The Oasis reached the height of its prosperity in the Roman era, and the cultivation of wheat, which was widely exported to the capital Rome (Hawass, Z. A., 2000).

In the Christian era, Bahariya Oasis frequently mentioned in the Christian heritage and the history of the Egyptian Coptic Church and found Christian monuments in Qasr - Mandishah - El-Bawiti - El Hayz. It also continued to be mentioned in the Middle Ages before Islam entered Egypt. After the entry of Islam to Bahariya continued its importance through the era of the Islamic Egypt as a whole as an important passage through the paths of the desert moved the trade convoys through. And visited by a number of travelers in the nineteenth century.

The work of Dr. Ahmed Fakhry in the twentieth century. Dr. Zahi Hawass then completed work at the end of the 20th century and the beginning of the 21 st century. Bahariya Oases is still the land of origin for archaeological work and for tourism and cultural investment prospects. 


\section{The Culture Heritage of Bahariya Oasis:}

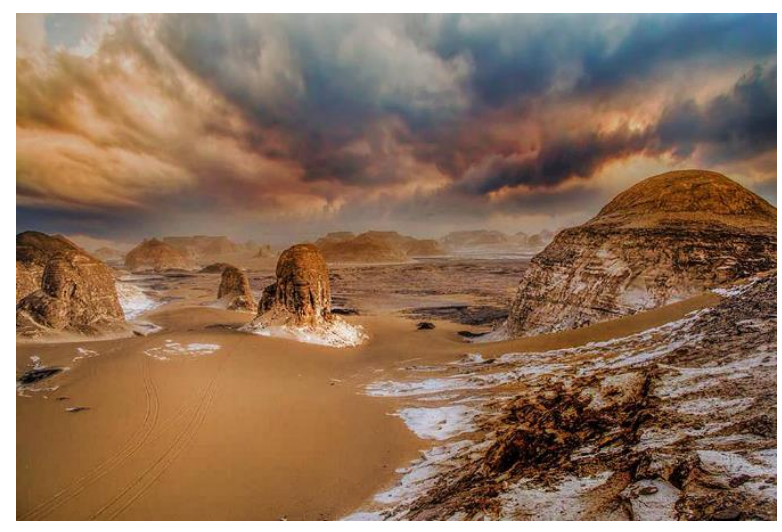

Fig. 2 White Desert in Bahariya Oasis

In Bahariya Oasis, there are large number of historical places; temples, chapels, tombs, tombs date back to the Saite dynasty, Tombs of El-Bawiti, Palace of Allam, Ain El-Meftela chapels, Temple of God Bes, Temple of Alexander the Great, The Golden Mummies Valley, GrecoRoman, Coptic and Islamic monuments, and a number of natural sites with fascinating views that are unmatched in the world, such as the eyes of natural water and environmental sites such as the Museum of the Heritage of Bahariya Oasis, the White and Black Desert, and Crystal Mount (Egyptian Monuments, 2018).

\section{Tombs of El-Bawiti}

The tomb of Amenhotep Huy is one of the oldest tombs of Bahariya Oasis (Van Siclen, C. C., 1981). these tombs were carved into the local sandstone, the nature of the area was the reason for the uniqueness of these tombs. The tombs of Bahariya Oasis are dated from the Late Period to the Saite period.

\section{Palace of Allam}

The Palace of Allam is a huge mud-brick building. Dr. Ahmed Fakhry defined the palace of Allam as a Roman war fortress (Fakhry, A., 1950). Until recently, scientists maintained this belief and cite it when talking about the presence of the Romans and their strong influence in the oases. It was believed that the palace of Allam dates back to the Islamic era and was restored by the Islamic and Coptic antiquities sector in the Supreme Council of Antiquities. The French Institute of Oriental Archeology sent a research team to work in that area and to examine the pottery found around the area and within the palace, the French team realized that it dates back to the twenty-sixth. 


\section{Ain El-Meftela chapels}

The $4^{\text {th }}$ chapels of Ain El-Meftela date back to the $26^{\text {th }}$ dynasty, the Saite period, to the same period as the tombs. The priest sheben Khonsu who was the supervisor of building these 4 chapels, and then completed by the governor of Bahariya Oasis Djed Khonsu auf'ankh in the time of King Ahmose II (Amasis). These chapels are located near Qasr village, near El-Bawiti. This area maned Ain-El-Meftela because it was close to the eye of the water called Ain ElMeftela located to the northeast of the chapels. It is one of the most important eyes of natural water in Bahariya Oasis (Fakhry, A., 1950).

\section{Temple of god Bes}

Near the chapels of Ain Meftela, it was found a small temple for god Bes, god of fun. The temple consists of a number of rooms that may have been reserved for Festivals. From this temple came the largest sandstone statue of the god until now and is in the Egyptian Museum in Cairo (Fakhry, A., 1950).

\section{Temple of Alexander the Great}

The temple of Alexander the Great is the only temple dedicated to this great Macedonian conqueror in Egypt until now. On the walls of the temple, Alexander the Great presented the offerings to the god Amun, one of the most important ancient Egyptian gods who worshipped in Bahariya Oasis in the Greco-Roman era. Perhaps, the establishing of this temple is a commemoration of the temple of Alexander's passing with Bahariya Oasis to the temple of the inspiration in the Siwa Oasis (Fakhry, A., 1950).

\section{The Golden Mummies Valley}

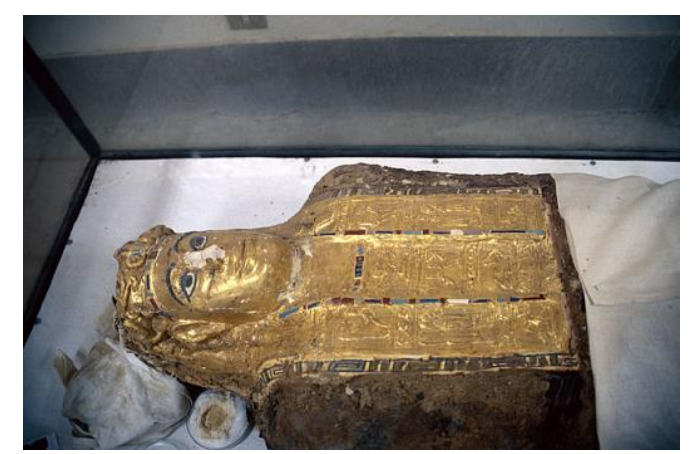

Fig. 3 Mummy found in the Valley of the Golden Mummies, now in El-Bawiti museum. 
In kilo 6 Bahariya and Farafra Oasis road, Dr. Zahi Hawas succeeded in discovering the golden mummies valley with 250 mummies, dating back to the first and second centuries AD when Egypt was under Roman rule. These discovered mummies show the continuity of the Egyptian religion during this period, despite the existence of the Greek and Roman beliefs of the ruling class, which in turn were influenced by the ancient Egyptian religion. Most of these mummies were discovered with gilded masks and chests decorated with hieroglyphic inscriptions and religious drawings (Hawass, Z. A., 2000).

\section{New Vision for Bahariya Oasis as A culture heritage site:}

According to UNESCO World Heritage Sites List that Egypt has seven Heritage Sites listed, on the other hand, there are 33 heritage sites on the tentative list tell now (Centre, 2018). Bahariya Oasis is on the tentative list of Egypt. It is a rich place in Cultural and Natural Heritage. Tourism is a new and important source of income for locals, and it has brought an international presence to the Oasis, therefore it is essential to know How to market this site and benefit from its treasures, this will be definitely by different steps as follow;

\section{$>$ Put Bahariya Oasis on the global Egyptian tourism map:}

Tourism is a new and important source of income for locals, and it has brought an international presence to the Oasis (Bliss, F., 2006). According to the Egyptian tourism map, Bahariya Oasis is not from the priority of the tourism companies in their plans, it must be our priority because the Egyptian Oasis will be our future of tourism for many Cultural, social and economic reasons.

\section{$>$ Organizing One day trip for the local community:}

Local trips are not from our priority in the tourism map of Egypt. On the other hand, local tourism, it will be the future of tourism in Egypt, therefore organizing local trips (one day tour) for different places inside Egypt, places well not known for the Egyptian community, are something essential nowadays. Bahariya Oasis is one of the places that the Egyptian will prefer it for many reasons, it is not far from Cairo, historical and natural place, healthy weather.

\section{Expanding the construction of healthy villages and Hotels in Oasis:}

Expanding the numbers of the healthy villages and Hotels at Bahariya Oasis is something essential nowadays. These will be by upgrading the existing hotels and upgrading them to suit the preservation of Bahariya Oasis and not destroy its unique natural environment. Also, establishing a larger number of diverse hotels, especially environmentally friendly, and construction and furnishing it with materials from the local environment. Paving roads leading to the archaeological sites and preparation of archaeological sites for the visit and marketing of tourism to these archaeological and tourism sites. 


\section{Focusing on the importance of Oasis in our educational curricula:}

Our Curricula in Egyptian has to have a full data about our cultural heritage sites including Bahariya Oasis, these will increase the community awareness toward our heritage and create some kind of continuity between the past, the present and the future for the other generations.

\section{Establishing a public railway station:}

The Baharia Military Railway was built to provide access to the Oasis through the World War I but after the increasing number of people in Bahariya, it needs to a regular public railway to decrease the time and serve the future of tourism in the Oasis, especially that the Oasis is not far from Cairo like the other Oasis in the western desert. Also, this line will serve the trade in this Oasis, this will also increase the national income of Egypt in the future.

\section{Conclusion}

Egypt has unique culture heritage dates back to thousands and thousands of years. This cultural heritage is between listed and unlisted in the world cultural and natural heritage sites list. It is important to still preserve and protect this heritage sites for the mankind. Bahariya Oasis is one of the Egyptian Cultural and Natural heritage sites, that is not listed in the world heritage sites list tell now. this Oasis famous of its Archaeological and Natural sites. In the Egyptian Tourism map, it has to have a management plan for Bahariya Oasis and make it as one of our priority for the future of tourism in Egypt. Therefore, this paper focuses on the heritage of this Oasis and try to find a new vision to benefit from it and used it as a source of the national income of Egypt.

\section{References}

- Bliss, F. (2006). Oasenleben: die ägyptischen Oasen Bahriya und Farafra in Vergangenheit und Gegenwart (Vol. 23). Politischer Arbeitskreis Schulen (PAS).

- Centre, U. (2018). Egypt - UNESCO World Heritage Centre. [online] Whc.unesco.org. Available at: http://whc.unesco.org/en/statesparties/eg [Accessed 27 Feb. 2018].

- Egyptian Monuments. (2018). Bawiti. [online] Available at: https://egyptsites.wordpress.com/2009/03/14/bawiti/ [Accessed 27 Feb. 2018].

- Fakhry, Ahmed: Bahria Oasis, vol. II. Cairo: Government Press, 1950, pp. 41-47

- Giddy, L. L. (1987). Egyptian oases: Bahariya, Dakhla, Farafra \& Kharga during Pharaonic times. Aris \& Phillips., 52

- Hassan, F. A. (1999). Baharia Oasis. Encyclopedia of the Archaeology of Ancient Egypt, Routledge, New York, 164.

- Hawass, Z. A. (2000). Valley of the golden mummies. Harry N. Abrams.

- Kujanova, M., Pereira, L., Fernandes, V., Pereira, J. B., \& Černý, V. (2009). Near Eastern 
Neolithic genetic input in a small oasis of the Egyptian Western Desert. American journal of physical anthropology, 140(2), 336-346.

- Lichtheim, M. (1976). Ancient Egyptian Literature. A Book of Readings, 1, 11-12.

- M. R. Bunson, Encyclopedia of Ancient Egypt, New York, 2002, p.14

- Van Siclen, C. C. (1981). Wall Scenes from the Tomb of Amenhotep (Huy), Governor of Bahria Oasis. CC Van Siclen.

Received: February 13, 2020

Accepted: April 29, 2020 